\title{
Az V. páneurópai vasúti közlekedési alap- folyosó és a szárnyvonalak magyarországi szakaszainak korszerúsítése. 1. rész
}

\begin{abstract}
A páneurópai közlekedési folyosókat, más néven: Helsinki-folyosókat, az 1994-es és 1997-es európai közlekedési miniszteri konferenciákon jelölték ki.
\end{abstract}

A tíz kijelölt folyosó a transzeurópai közlekedési hálózat (TEN-T) kiterjesztése Kelet-Európa, az akkori Európai Unió szomszédos államai irányába.

A folyosók kijelölésének célja a jó közlekedési kapcsolatok kiépítése volt az EU és a vele szomszédos országok között, a hatékony és biztonságos közlekedési rendszer kialakítása révén, segítve az utasok és áruk hatékony szállítását, és ezáltal a versenyképességet és a gazdasági növekedést.

Az Európai Unió bővítése során ezek a folyosók ma már nagyrészt az EU területén haladnak, így a transzeurópai közlekedési hálózat (TEN-T) részét képezik.

DOI 10.24228/KTSZ.2018.3.2

\section{Balogh Imre}

ny. MÁV mérnök főtanácsos

e-mail: balogh.imre39@gmail.com

\section{BEVEZETÖ}

Az első, 1991-ben Prágában megrendezett konferencia eredményeként a résztvevők egy közlekedési folyosókon alapuló, államok közötti vasúti, közúti és vízi megközelítés kialakításában állapodtak meg.

A második konferencián,1994-ben Krétán, kilenc páneurópai közlekedési folyosót jelöltek ki. Ezek Kelet-Európa fő közlekedési tengelyei, és ezekre kívánták összpontosítani a közlekedési infrastruktúra fejlesztésére rendelkezésre álló erőforrásokat.

A harmadik konferencián 1997-ben Helsinkiben, a balkáni államok lobbizásának köszönhetően, egy tizedik páneurópai folyosót is kijelöltek. Ugyanezen a konferencián négy „páneurópai közlekedési területet” is kijelöl- 


\section{Vasúti közlekedés}

tek, amelyek tengeri medencéket foglalnak magukba.

A kelet- és kelet-középeurópai politikai fordulatok elősegítették a páneurópai gondolkodás érvényesítését a közlekedéstervezésben is. Az 1997-ben meghatározott folyosók egy transzeurópai közlekedési hálózatot képeznek. Fő céljuk észak-déli irányban, az Északi-tenger és a Földközi-tenger, kelet-nyugati irányban pedig a bővítés előtti EU és a volt szovjet utódállamok közötti megfelelő kapcsolat megteremtése.

Magyarország ezen transzeurópai folyosók találkozásában fekszik. A tizennyolc folyosó közül hat keresztülhalad hazánkon.

Európa-Ázsia zavartalan és minden igényt kielégítő forgalmát - Ukrajna, Oroszország és a FÁK országok vasúti nyomtávkülönbsége miatt - Kelet-Európa vasútvonalain keresztül lehet lebonyolítani, beleértve a Nyugat-Európában kiépült nagysebességủ vasúthálózatot is.

\section{ELÖZMÉNYEK}

\subsection{Az európai közlekedéspolitika}

A közlekedéspolitika több mint 30 éve az uniós közös politikák egyike, amelyet az Európai Unió Bíróságának 1985. május 22-i, az Európai Parlament által a Tanáccsal szemben mulasztás megállapítása iránti keresetről hozott ítélete indított útjára.

A közlekedési piacok verseny előtti megnyitása és a transzeurópai hálózatok megteremtése mellett 2020-ig egyre nagyobb jelentőséget kap a „fenntartható mobilitás” témaköre.

Ez elsősorban azzal van összefüggésben, hogy az üvegházhatású gázok kibocsátása folyamatosan nő az ágazatban, ami veszélyezteti az Európai Unió éghajlattal kapcsolatos célkitüzéseinek megvalósulását.

$\mathrm{Az}$ Európai Unió közlekedéspolitikájának alappillére egy társadalmi-gazdasági és környezetvédelmi szempontból egyaránt fenntartható közlekedési rendszer kialakítása.
Ehhez az alábbi tényezők között kellett megteremteni az egyensúlyt, mint:

- a gazdasági és társadalmi igények,

- a közlekedés összehangolt fejlesztése,

- a fenntartási és üzemeltetési tevékenység harmonizálása,

- a rendelkezésre álló források fejlesztés arányos megosztása.

Az első Fehér Könyvet, amely a közlekedési infrastruktúra fejlesztésére vonatkozó Uniós ajánlásokat tartalmazta 1992-ben adta ki az Európai Bizottság.

Az európai közlekedéspolitika összességében, a hálózati infrastruktúra kiépítését célozza meg, de valójában ennél több: a közlekedési, a távközlési és a vezetékes energiaszállítási rendszerek összekapcsolásáról, a teljes rendszer változó feladatokra alkalmas átalakításáról van szó.

A TEN-hálózat kialakításával az EU célja akohézió erősítése, mert az összekapcsolt hálózatok egész Európában hatékonyabb közlekedést és szállítást tesznek lehetővé, ami által a peremterületek elérése is javul. Segítségével lehetővé válik az Európai Közösség, mint integrációs egység, harmonikus területi-gazdasági együttműködése.

A TEN-koncepció az egységes infrastruktúra rendszer kialakításának irányelveit fogalmazza meg, keretet adva az összehangolt fejlesztéseknek. A TEN-T a TEN messze legnagyobb alrendszerét képező közlekedési hálózatokat tartalmazza.

Az EU bővítése miatt a transzeurópai hálózat kiegészítése szükségessé vált. A belépő országok közlekedési infrastruktúrájának a TENnel való összekapcsolását szolgálta, az 1996ban indult TINA program. A TINA a TEN kiterjesztése Európán kívülre.

Az itt meghatározott hálózati elemek gerinchálózatra és kiegészítő elemekre oszthatók. A program a hálózati elemek mellett forgalomszabályozó rendszereket is tartalmaz. 


\section{Vasúti közlekedés}

\subsection{Magyar közlekedéspolitika}

Az Országgyülés által 1996-ban elfogadott közlekedéspolitika stratégiai iránya az Európai Unióhoz való csatlakozás elősegítése volt.

Közlekedéspolitikánk ennek érdekében súlyponti feladatként jelölte meg a hazai közlekedési joganyag harmonizációját a Közösség jogszabályaival. A dokumentum ugyanakkor leszögezi, hogy a magyar közlekedési piac szereplőinek korlátozott versenyképessége miatt, versenyesélyünk javítása érdekében a jogharmonizáció során szükség van a fokozatosság, az átmenet biztosítására.

A magyar közlekedéspolitika szükségesnek tartotta és tartja, hogy az Európai Unióhoz való csatlakozásunk feltételeinek javítása érdekében, majd EU tagként, a közlekedés pályahálózatának fenntartása és jármüállományának korszerüsítése terén mutatkozó lemaradás folyamatosan és lényegesen csökkenjen.

A költségvetési források elosztása során kiemelten kellett figyelembe venni a tranzitútvonalak fejlesztését, elsősorban az Európai Unió által előnybe részesített közlekedési folyosók hazánkat érintő elemeinek megépítését, átépítését.

A magyar közlekedéspolitika a közösségi elvekkel összhangban célul tüzte ki:

- A közlekedés állami szerepvállalásának csökkentését ott, ahol ez a széles értelemben vett gazdasági és társadalmi érdek figyelembevétele mellett lehetséges.

- A többségi állami tulajdonú társaságoknál a tökebevonásos, részleges privatizációt.

- Az országos közforgalmú hálózatok fejlesztésénél a költségvetési terhek mérséklése érdekében a vegyes finanszírozási konstrukció alkalmazását.

- Az infrastruktúra használatával kapcsolatos költségek fokozatos megfizettetését az igénybevevőkkel.

- A magántőke az építésre fordított költségekkel arányosan bizonyos ideig részesül a beruházás bevételeiből, majd a létesítményt átadja az államnak. Hazánkban koncesszió keretében a kizárólagos állami tulajdonban lévő közúthálózat egy részét, - azaz egyes autópálya-szakaszokat - magántársaságok építettek meg, és ellentételezésként 25 évre megkapták az üzemeltetés és ezen keresztül az autópálya használati díj szedésének jogát.

A hazai közlekedéspolitika - okulva a fejlett európai országokban a motorizációs robbanás idején érvényesített, a közúti közlekedést elötérbe helyező politika kudarcából - azt tartja követendőnek, hogy a vasúti és a vízi szállítás részarányát legalább őrizzük meg, és esetleg növeljük a Nyugat-Európában kialakultnál magasabb szintre.

A közösségi közlekedés részarány-csökkenési ütemét mérsékeljük, és növeljük a kombinált árufuvarozások részarányát.

\section{A PÁNEURÓPAI FOLYOSÓK}

A harmadik konferencián 1997-ben a Helsinkiben elfogadottak szerint, a tíz páneurópai közlekedési folyosót, az 1. ábra mutatja be.

I. Helsinki-Tallinn-Riga-KalinyingrádGdańsk és Vilnius-Varsó

II. Berlin-Poznań-Varsó-BresztMinszk-Szmolenszk-MoszkvaNyizsnyij Novgorod

III. Berlin/Drezda-Wrocław-KatowiceKrakkó-Lviv-Kijev

IV. Drezda/Nürnberg-Prága-BrnoPozsony-Győr-Budapest-AradCraiova-Szófia-Plovdiv-Isztambul

V. Velence-Trieszt/Fiume-LjubljanaMaribor-Budapest-Ungvár-LvivKijev

VI. Gdańsk-Grudziądz-ToruńZebrzydowice-Zsolna

VII. A Duna, elérhető az Északi-tenger a Rajna-Majna-Duna-csatornán keresztül 


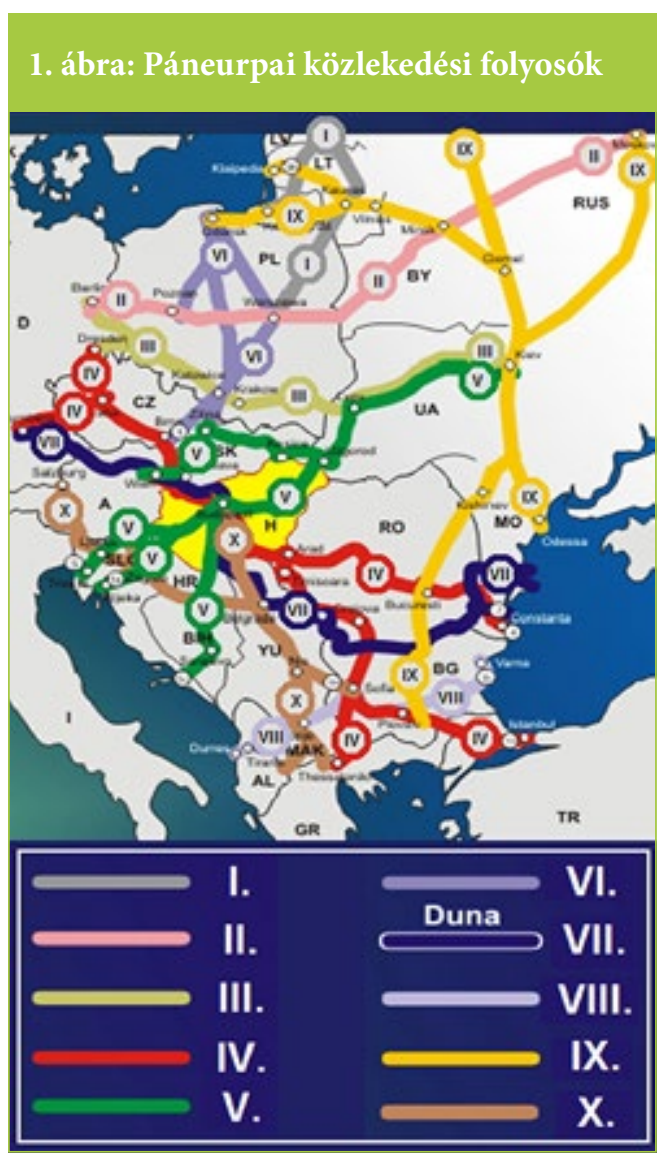

VIII. Durrës-Tirana-Szkopje-BitolaSzófia-Plovdiv-DimitrovgradBurgasz-Várna

IX. Helsinki-Viborg-SzentpétervárMoszkva-Kijev-LjubasevkaChișinău-Bukarest-DimitrovgradOrmenio-Alexandrúpoli

X. Salzburg-Ljubljana-Zágráb-BelgrádNiš-Szkopje-Szaloniki.

Ezek a közlekedési folyosók a vasútvonalakat, a közutakat és a vízi utakat foglalják magukba.

\subsection{Az V. számú páneurópai folyosó}

\subsubsection{Az alapfolyosó}

$\mathrm{Az}$ V. sz. páneurópai vasúti alapfolyosó az északkelet - adriai kikötők, Olaszország-Szlo- vénia - Magyarország és Ukrajna közötti öszszeköttetést jelenti.

\section{NYOMVONALA:}

Velence-Trieszt/Koper-LjubljanaBudapest-Hatvan-Miskolc-NyíregyházaZáhony-Ungvár-Lvov-Kijev.

\section{VONALSZAKASZOK:}

\subsubsection{Velence-Trieszt vasútvonal}

Kétvágányú normálnyomtávolságú vasúti fóvonal, $3 \mathrm{kV}$ egyenárammal villamosított. Hossza $153 \mathrm{~km}$.

\subsubsection{Trieszt-Ljubjana vasútvonal}

Kétvágányú normálnyomtávolságú fővonal, $3 \mathrm{kV}$ egyenárammal van villamosítva. Hossza $144 \mathrm{~km}$.

\subsubsection{Koper-Divaca vasútvonal}

Egyvágányú normálnyomtávolságú, 3000 V villamosított vasútvonal. Hossza $50 \mathrm{~km}$.

\subsubsection{Divaca-Ljubljana vasútvonal}

A Ljubljana-Divaca vasútvonal Szlovénia egyik legfontosabb $3000 \mathrm{~V}$ egyenárammal villamosított, kétvágányú fővonala. Az engedélyezett legnagyobb sebesség $160 \mathrm{~km} / \mathrm{h}$. Hossza $103 \mathrm{~km}$.

\subsubsection{Ljubljana - Budapest vasútvonal}

A vonal teljes hossza $532 \mathrm{~km}$. A magyar vonalszakasz egyvágányú, $25 \mathrm{kV} 50 \mathrm{~Hz}$ áramrendszerrel villamosított. Ezt az áramrendszert építtték ki a szlovén határtól a vonalon és Hodos vasútállomáson.

A Pragersko-Hodos vasútvonal 109 kilométernyi szakaszát korszerüsítették, $160 \mathrm{~km} / \mathrm{h}$ sebességre alkalmasan, $25 \mathrm{kV} 50 \mathrm{~Hz}$ áramrendszerrel villamosítva, 2016-ban.

3.1.1.6. Budapest - Miskolc - Nyíregyháza-
Záhony - Csap vasútvonal
Átépítésre váró vasútvonal. Hossza $348 \mathrm{~km}$.

\subsubsection{Csap-Kijev vasútvonal}

Munkács városon át vezető, egyvágányú, széles nyomtávolságú, $3 \mathrm{kV}$ egyenárammal villamosított. Hossza $888 \mathrm{~km}$. 


\section{Vasúti közlekedés}

A teljes alapfolyosó hossza: $2218 \mathrm{~km}$. A normálnyomtávolságú vágány hossza $1330 \mathrm{~km}$.

\subsection{Szárnyvonalak}

\subsubsection{V/A. Szlovákia-Ukrajna szárazföldi kapcsolata}

\section{NYOMVONALA: \\ Pozsony-Zsolna-Kassa-Ungvár}

\section{VONALSZAKASZOK:}

\subsubsection{A Pozsony-Zsolna vasútvonalszakasz} Puhó állomáson keresztül köti össze Pozsonyt Zsolnával. A vasútvonal jelölése Szlovákiában, 120-as fővonal, amely normálnyomtávolságú, kétvágányú és villamosított. Engedélyezett sebesség $160-120 \mathrm{~km} / \mathrm{h}$.

\section{A vasútvonal érdekessége a kettős villamos- vontatás:}

- A Pozsony-Puhó szakasz és a köztes állomások vontatási villamos áramellátási rendszere $25 \mathrm{kV}, 50 \mathrm{~Hz}$ - AC (váltakozó áram).

- Puhó külterület - Zsolna szakasz ellátási rendszere $3 \mathrm{kV}$ - DC (egyenáram).

A villamosenergia rendszerek sokáig az alsókocskóci vasútállomáson kapcsolódtak, Puhótól 2,1 km-re délre. Ez az állapot azonban, a pálya rekonstrukciójával megváltozott. 2015. augusztus 1-jén Puhó állomást is bekapcsolták a váltakozó áramú hálózatba, így az energiarendszerek két helyen kapcsolódnak: Horní Lideč irányába a nyugati, Zsolna irányába az északi állomáson. Ilyen módon az egyáramrendszerű mozdonyok Pozsonyból már Puhóig közlekedhetnek. Ugyanakkor ez bonyolítja a cseh és szlovák tehervonatok áthaladását, illetve a vonatok üzemeltetését a (Prága) - Horní Lideč-Puhó -Zsolna viszonylaton. A vonalszakasz hossza $203 \mathrm{~km}$.

A ŽSR tervei szerint Zsolna vasútállomást 2022ben kapcsolják be a nagyfeszültségü hálózatba. A rekonstrukció befejezése után a PozsonyZsolna-Kassa viszonylat minden szakasza 25 kV-os váltakozó árammal villamosított lesz.

\subsubsection{Zsolna-Kassa vasútvonal szakasz}

Kétvágányú, villamosított fövonal. A vonal jelölése Szlovákiában 180-as. A szakasz ellátási rendszere $3 \mathrm{kV}$ - DC (egyenáram). Hossza $239 \mathrm{~km}$. Engedélyezett sebesség $120 \mathrm{~km} / \mathrm{h}$.

A vonalszakasz átépítésének első üteme 2011ben befejeződött az új Zsolna-Hernádtapolca rendezőpályaudvar építésével. A Tátra hegység alatt vezető vasúti szakasz modernizációja 2015 után kezdődött. Nem csak a vasútvonalat, de Csorba vasútállomás épületét is felújítják. A vasútvonal új müszaki paraméterekkel épül át. A $200 \mathrm{~km} / \mathrm{h}$ maximális üzemi sebesség és a $160 \mathrm{~km} / \mathrm{h}$ minimum tervezési sebesség miatt Csorba és Szvit között három kilométer hosszan új nyomvonalra is kerül, ami miatt a szakasz teljes hossza 168 méterrel rövidül.

\subsubsection{Kassa-Ungvár vasútvonal szakasz}

\section{Normálnyomtávú kapcsolat}

Kassa és Ungvár között nincs közvetlen normálnyomtávolságú vasúti kapcsolat. A normalnyomtávú kapcsolat KassaTiszacsernyő-Csap határátmeneten keresztül áll fenn, ami kétvágányú villamosított fővonal Tiszacsernyőig. Jelölése Szlovákiában190es vonal. A szakasz ellátási rendszere $3 \mathrm{kV}$ - DC (egyenáram). Hossza 98,75 km. Engedélyezett sebesség 120/100 km/h. Tiszacsernyő és Csap vasútállomások között egyvágányú villamosított normal- és széles nyomtávú kapcsolat van.

\section{Széles nyomtávú kapcsolat}

Egyvágányú, széles nyomtávú villamosított vasútvonal Szlovákia és Ukrajna között, amely a Kassa alatti Enyicskén működő kohó vasérc és kohóalapanyag szállítására épült. A szakasz ellátási rendszere $3 \mathrm{kV}$ - DC (egyenáram). Hoszsza $94 \mathrm{~km}$. Engedélyezett sebesség 50-60 km/h.

Az Ungvár-Enyicke vasútvonal a kárpátaljai Ungvárnál kezdődik, majd közel $8 \mathrm{~km}$ után belép a Szlovák Köztársaság területére és továbbhalad a határtól két kilométerre lévő Mátyócvajkóc (Matovce) vasútállomás felé. A pálya ezután Tőketerebesig halad párhuza- 
mosan a normálnyomtávú Bánóc-Nagykapos vasútvonallal, amely a 42,105 kilométerszelvényben csatlakozik a tőketerebesi vasútvonalakhoz. Az egyetlen rövid kivétel a Bánócot délről elkerülő szakasz, ahol a vasútvonal eltérö nyomvonalon halad az 1435 mm-es nyomtávú vonaltól. A vasútvonal Kalsa mellett találkozik a kétvágányú Kassa-TiszacsernyőCsap vasútvonallal, majd ezzel párhuzamosan halad a Kassától délre fekvő Enyickéig, ahol a széles nyomtávú vasúti tároló és az acélmű is található. A pályát 1978-ban villamosították, a régióban egységesen használt $3 \mathrm{kV}$ egyenáramú vontatási rendszer épült ki.

\subsubsection{A Csap-Ungvár vasútvonal szakasz}

A vasútvonal egyvágányú, villamosított, széles nyomtávú (1520 mm), Szambir-Lviv vasúti fóvonal Ukrajnában. Hossza $22 \mathrm{~km}$. A szakasz ellátási rendszere $3 \mathrm{kV}$ - DC (egyenáram). Ungvártól Uzsokig az Ung völgyében halad. A történelmi határt az Uzsoki-hágónál lépi át.

Az V/A szárnyvonal teljes hossza: 536,88 km. Ebből 442,88 km normál- és 94 km széles nyomtávú vasúti pálya.

\subsubsection{V/B. Horvátország-Magyarország kikötöi kapcsolata}

NYOMVONALA:

Fiume-Zágráb- Budapest

\section{VONALSZAKASZOK:}

\subsubsection{Fiume-Zágráb vasútvonal}

Normálnyomtávolságú, egyvágányú, $25 \mathrm{kV}$ $50 \mathrm{~Hz}$ áramrendszerrel villamosított vasútvonal. Hossza: $228 \mathrm{~km}$.

\subsubsection{Zágráb-Koprivnica vasútvonal}

Normálnyomtávolságú, egyvágányú, $25 \mathrm{kV}$ $50 \mathrm{~Hz}$ áramrendszerrel villamosított vasútvonal. Hossza: $78 \mathrm{~km}$.

\subsubsection{Koprivnica-Gyékényes-Dombóvár vasútvonal}

Normálnyomtávolságú, egyvágányú, $25 \mathrm{kV}$ $50 \mathrm{~Hz}$ áramrendszerrel villamosított vasútvonal. Hossza: $101 \mathrm{~km}$.

\subsubsection{Dombóvár-Budapest vasútvonal}

Normálnyomtávolságú, egyvágányú, $25 \mathrm{kV}$ $50 \mathrm{~Hz}$ áramrendszerrel villamosított vasútvonal. Hossza: $164 \mathrm{~km}$.

\section{A szárnyvonal hossza Budapestig $571 \mathrm{~km}$.}

\subsubsection{V/C. Horvátország-Bosznia-Hercego- vina-Magyarország kikötői kapcsolata}

\section{NYOMVONALA: \\ Ploce-Szarajevo-Eszék-Budapest}

A daytoni békemegállapodás alapján a létrejött ország két entitásra tagolódik: a BoszniaHercegovinai Föderációra és a Boszniai Szerb Köztársaságra. A két entitás területére eső vasútvonalakat ennek megfelelően két vasúttársaság kezeli: a Bosznia-Hercegovinai Föderáció Vasútja ŽFBH és a Boszniai Szerb Köztársaság Vasútja ŽRS. Bosznia összes vasúthálózatának hossza mintegy $1033 \mathrm{~km}$, jórészt nehéz, hegyvidéki és folyókkal szabdalt terepen halad.

A ŽRS $425 \mathrm{~km}$ vasútvonalat kezel, a fővonalak Volinja-Banja Luka-Doboj és SamacDoboj-Maglaj-Szarajevo $25 \mathrm{kV} 50 \mathrm{~Hz}$ rendszerrel villamosítottak. A háború igencsak megviselte a felsővezeték hálózatot, de a legfontosabb fövonalakon a háború után gyorsan megindult az újjáépítés. A másik entitásban a ŽFBH összesen $608 \mathrm{~km}$ vasútvonalat kezel. A kétvágányú szakasz hossza csak mintegy 90 km. A ŽFBH részéről, a DobojMaglaj-Szarajevó-Mostar-Ploče vasútvonal villamosított.

\section{VONALSZAKASZOK:}

3.2.3.1. Ploce-Metkovic szakasz

Horvátország vasútvonala. Hossza $23 \mathrm{~km}$.

\subsubsection{Metkovic-Mostár-Sarajevo-Samac} szakasz

Bosznia-Hercegovina vasútvonala. Hossza: $326 \mathrm{~km}$.

\subsubsection{Samac-Osijek-Magyarbóly szakasz}

Egyvágányú nem villamosított vasútvonal Osiek és Magyarbóly között. A teljes szakasz hossza: $103 \mathrm{~km}$. 


\section{Vasúti közlekedés}

2. ábra

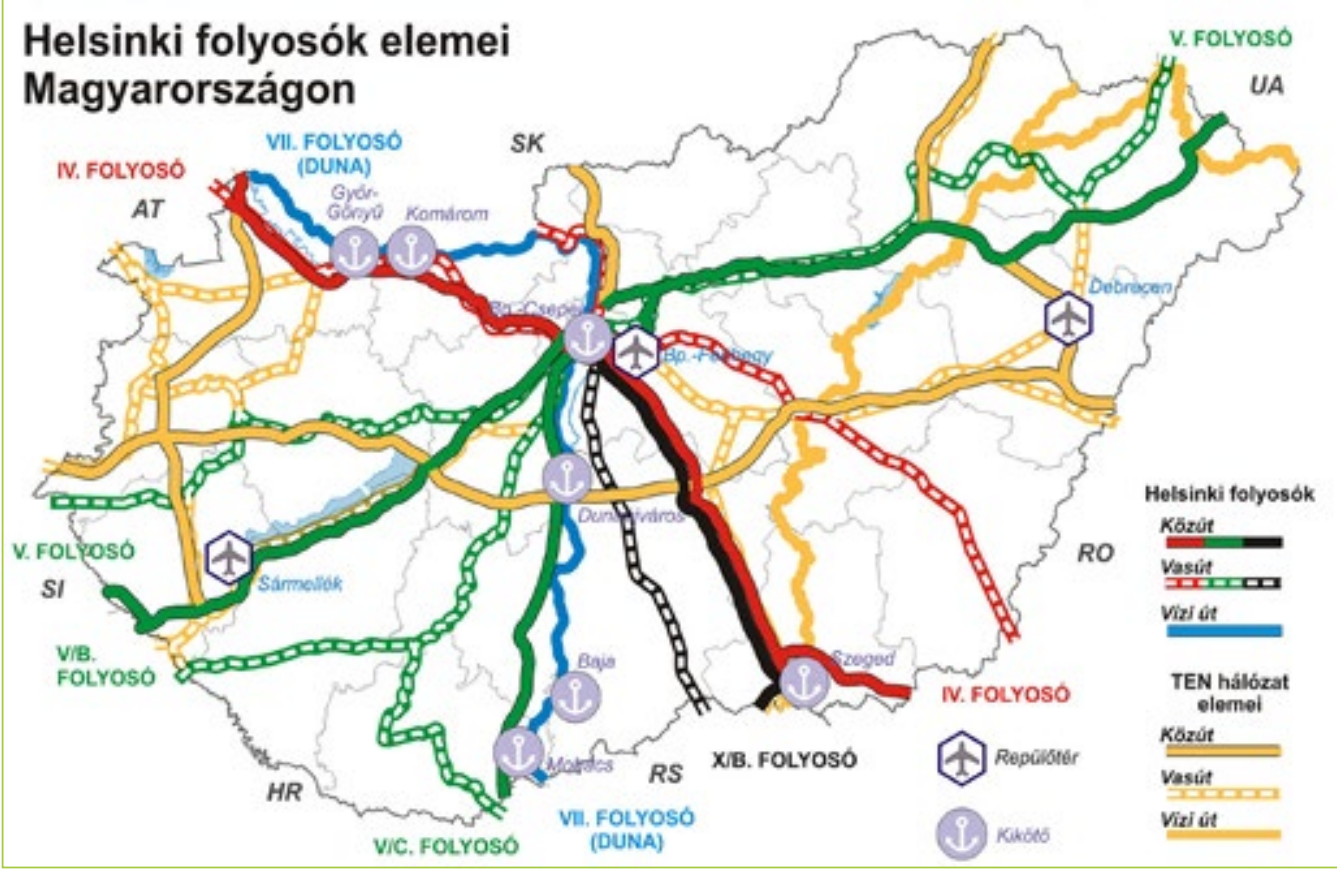

\subsubsection{Magyarbóly-Budapest szakasz}

Egyvágányú nem villamosított vasútvonal Pécsig. Engedélyezett sebesség $80 \mathrm{~km} / \mathrm{h}$.

Pécstől egyvágányú, $25 \mathrm{kV} 50 \mathrm{~Hz}$ rendszerrel villamosított vonal. Engedélyezett sebesség $100-120 \mathrm{~km} / \mathrm{h}$. A szakasz teljes hossza: $278 \mathrm{~km}$.

\section{A PÁNEURÓPAI FOLYOSÓK MAGYAR SZAKASZAI ÉS ELEMEI}

A páneurópai közlekedési folyosók, a TEN hálózattal együtt komplex infrastruktúrafejlesztést jelentenek Magyarország számára. A folyosók elhelyezkedését a 2. ábra mutatja.

- A IV. számú folyosó Ausztria és Szlovákia határától Budapesten keresztül, SzolnokBékéscsaba-Lökösháza vasútvonalon, Románia felé halad. A folyosó $417 \mathrm{~km}$ vasútvonalat és $410 \mathrm{~km}$ közutat tartalmaz.

- Az V. alapfolyosó a délnyugati országhatártól északkeleti irányban halad. Maga az alapfolyosó Szlovéniából lép be Magyarországra, Budapesten keresztül Miskolc-Nyíregyháza-Záhony vonalszakaszon folytatódik Ukrajna felé.

Az alapfolyosó magyar szakaszának hossza $617 \mathrm{~km}$.

$\mathrm{Az}$ V/B és V/C vasúti szárnyvonalak Horvátország felől lépik át az országhatárt, és Dombóvárnál egyesülve folytatódnak Budapest felé.

A vasúti szárnyvonalak hossza összesen 376 km, ebből: V/B 265 km, V/C 111 km.

- A VII. folyosó a Duna. A vízi út az Északitengert, a Rajna-Majna-Duna-csatornán keresztül köti össze a Fekete-tengerrel.

Teljes 2415 km hosszú vízi út kikötői: Rotterdam-Mainz-Frankfurt-Bamberg-Regensburg- Passau-Linz-Bécs-Pozsony-Győr-Gönyü-Budapest-Csepel-Dunaújváros-Baja- 


\section{Vasúti közlekedés}

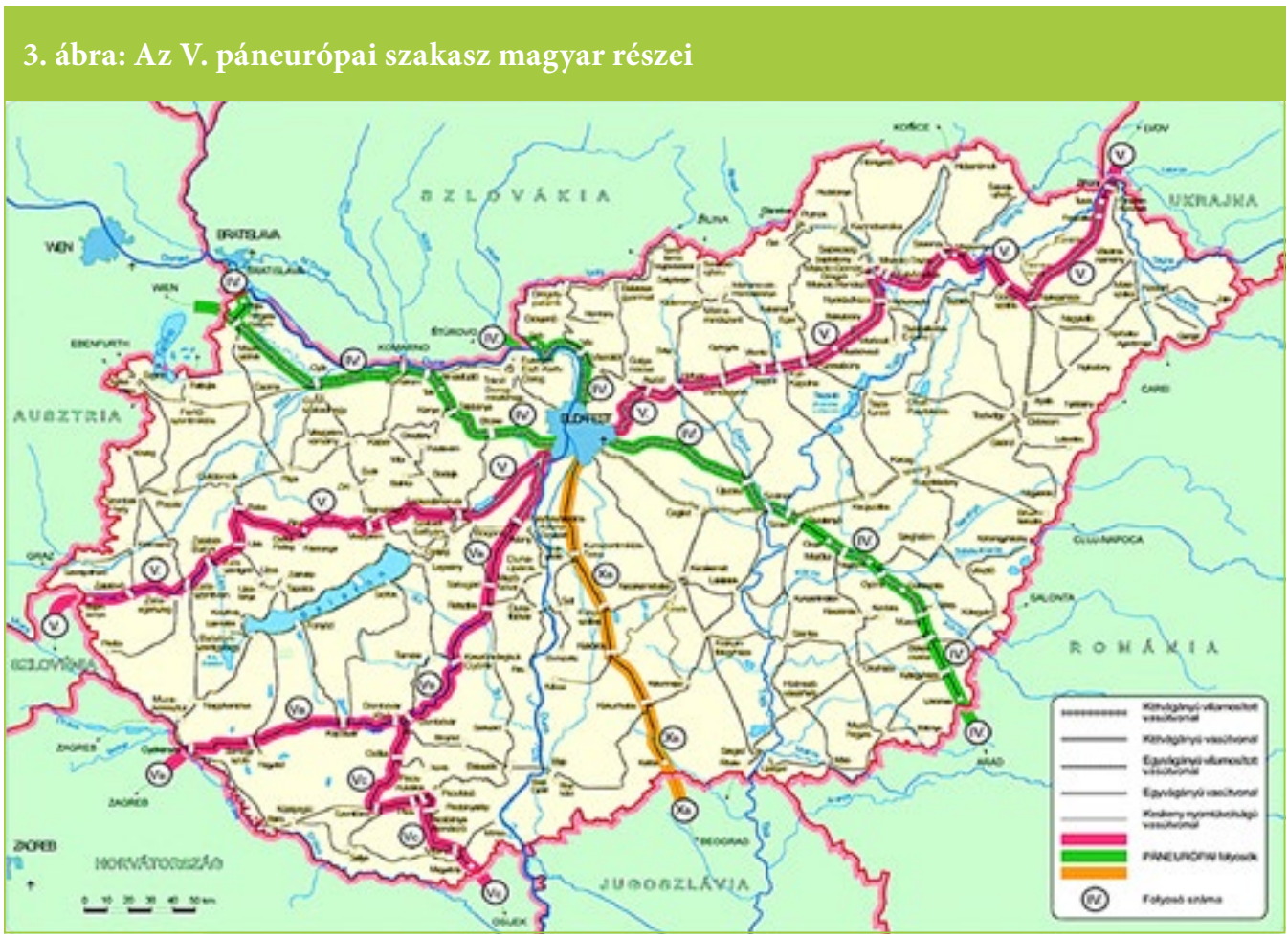

Mohács-Belgrád-Silistra-Konstanca-GalatIzmail

A magyarországi szakasz hossza $378 \mathrm{~km}$.

- A X. folyosó X/B szárnyvonala Budapestről indul Belgrádig. A vasúti szárnyvonal hoszsza 156 km, a közúti szakaszé $171 \mathrm{~km}$.

\section{A Páneurópai folyosók és szárnyvonalaik hossza összesen:}

Vasút: 1566 km

Közút: 587 km

Víziút: $378 \mathrm{~km}$

\section{AZ V. SZÁMÚ PÁNEURÓPAI FOLYOSÓ MAGYAR SZAKASZAI ÉS NYOMVONALAI}

A vasúti alapfolyosó és szárnyvonal szakaszok nagy jelentőséggel bírnak a nemzetközi és a belföldi személy- és áruszállításban. A magyarországi alapszakasz, valamint a szárnyvonalak együttes hossza: $993 \mathrm{~km}$.
$\mathrm{Az} \mathrm{V}$. páneurópai vasúti alapfolyosó szakasz és szárnyvonalak magyar részeit a 3. ábra mutatja be.

\subsection{Az V. alapfolyosó szakasz}

NYOMVONALA:

Bajánsenye-Zalaegerszeg-Boba-Székesfehérvár-Budapest-Miskolc-Nyíregyháza-Záhony.

\section{VONALSZAKASZOK:}

\subsubsection{Bajánsenye-Zalaegerszeg-Ukk-Boba vonalszakasz}

A MÁV ZRt. 25. számú vonalszakasza. Hoszsza: $101 \mathrm{~km}$. Egyvágányú, villamosított nemzetközi fővonal. Engedélyezett maximális sebesség: 100-160 km/h.

\subsubsection{Boba-Veszprém-Székesfehérvár vonalszakasz}

A MÁV ZRt. 20. számú vonalszakasza. Hoszsza: $114 \mathrm{~km}$. Egyvágányú, villamosított nemzetközi fővonal. Engedélyezett maximális sebesség: $100-80 \mathrm{~km} / \mathrm{h}$. 


\section{Vasúti közlekedés}

\subsubsection{Budapest-Székesfehérvár vonalsza- kasz}

A MÁV ZRt. 30a. számú vonalszakasza. Hoszsza: $67 \mathrm{~km}$. Kétvágányú, villamosított fővonal. Engedélyezett maximális sebesség: 100-120$160 \mathrm{~km} / \mathrm{h}$.

\subsubsection{Budapest-Miskolc-Szerencs-Nyíregy- háza vonalszakasz}

A MÁV ZRt. 80. számú vonalszakasza. Hossza: $278 \mathrm{~km}$. Kétvágányú, villamosított nemzetközi fövonal Mezözomborig. MezőzomborNyíregyháza között egyvágányú, villamosított fövonal. Engedélyezett maximális sebesség: $120-100-80 \mathrm{~km} / \mathrm{h}$.

\subsubsection{Nyíregyháza - Záhony szakasz}

A MÁV ZRt.100. számú vonalszakasza. Hoszsza: $66 \mathrm{~km}$. Kétvágányú, villamosított nemzetközi fővonal Tuzsér állomásig. Tuzsértól-Záhonyig egyvágányú, villamosított nemzetközi fővonal. Engedélyezett maximális sebesség: $80-100-120 \mathrm{~km} / \mathrm{h}$.

Az alapfolyosó magyar szakaszának teljes hossza: $617 \mathrm{~km}$.

\subsection{Az V/B szárnyvonal}

\subsubsection{Gyékényes-Dombóvár vonalszakasz}

A MÁV ZRt. 41. számú vonalszakasza. Hossza: 101 km. Egyvágányú, villamosított nemzetközi fővonal. Engedélyezett maximális sebesség: $100 \mathrm{~km} / \mathrm{h}$.

\subsubsection{Dombóvár-Pusztaszabolcs vonalsza- kasz}

A MÁV ZRt. 40. számú vonalszakasza. Hoszsza: $111 \mathrm{~km}$. Egyvágányú villamosított nemzetközi fővonal. Engedélyezett maximális sebesség: $120 \mathrm{~km} / \mathrm{h}$.

\subsubsection{Budapest-Pusztaszabolcs vonalsza- kasz}

A MÁV ZRt. 40a. számú vonalszakasza. Hoszsza: 53 km. Kétvágányú, villamosított nemzetközi és elővárosi fővonal. Engedélyezett maximális sebesség: $120-100-80 \mathrm{~km} / \mathrm{h}$.

Az V/B folyosó szárny magyar szakaszának teljes hossza: $265 \mathrm{~km}$.

\subsection{Az V/C szárnyvonal}

\subsubsection{Magyarbóly - Pécs vonalszakasz}

A MÁV ZRt. 65. számú vonalszakasza. Hoszsza: $43 \mathrm{~km}$. Egyvágányú, nem villamosított nemzetközi fővonal. Engedélyezett maximális sebesség: $80 \mathrm{~km} / \mathrm{h}$.

\subsubsection{Pécs-Dombóvár vonalszakasz}

A MÁV ZRt. 40. számú vonalszakasza. Hoszsza: $68 \mathrm{~km}$. Egyvágányú, villamosított nemzetközi fóvonal. Engedélyezett maximális sebesség: $80 \mathrm{~km} / \mathrm{h}$.

Az V/C folyosó szárny magyar szakaszának teljes hossza: $111 \mathrm{~km}$.

Az V. számú páneurópai alapfolyosó kiépítése és korszerüsítése Magyarországon 1998 évben kezdődött.

\section{HELYZETFELMÉRÉS}

$\mathrm{Az}$ V. számú vasúti alapfolyosónak nem volt Zalalövőtől Bajánsenyéig és onnan az országhatárig, Magyarországot Szlovéniával összekötő vasúti kapcsolata.

$\mathrm{Az}$ 1968. évben kihirdetett Közlekedéspolitikai Koncepció rögzítette egyes kisforgalmú vasútvonalak bezárását és forgalmuk közútra terelését. A megszüntetendő vonalak listáján szerepelt a Zalalövő-Bajánsenye vonal is, amelyen 1980. október 18-án szünt meg a forgalom. Rövidesen a pályát is elbontották. A vonal a koncepció egyik utolsó áldozata volt.

Az EU ajánlások a vasúti közlekedési folyosókra általában a kétvágányú, villamosított vasúti pályák kialakítását helyezték előtérbe.

A magyar alapfolyosó szakasz Zalalövőtől Székesfehérvárig egyvágányú és részben villamosított vonalszakaszokat foglalt magába. Székesfehérvár és Budapest között a vasúti pálya kétvágányú, villamosított vonalszakaszként funkcionált.

A Budapest-Miskolc-Szerencs-NyíregyházaZáhony vonalszakasz, a fentiekben már leírtak szerint, a Szerencs-Nyíregyháza, valamint 


\section{Vasúti közlekedés}

Tuzsér-Záhony viszonylat kivételével villamosított, kétvágányú pályán bonyolította le a személy- és az áruforgalmat.

Az alapfolyosón két vonalszakaszán kellett új feladatokat megoldani, úm.:

- A Bajánsenye-Zalalövő szakasz újbóli megépítése,

- A Tisza, Tokaj-Rakamaz közötti mederhíd, valamint az ártér hídjainak és földműveinek átépítése vagy új nyomvonalon való megépítése.

A Szolnok-Debrecen-Miskolc vasútvonal részeként 1859 májusában adták át a forgalomnak a Debrecen-Nyíregyháza-Tokaj- Szerencs-Miskolc vonalszakaszt. Az átadás után a vidék társadalmi-gazdasági viszonyai megváltoztak, a korábbi vármegyeszékhely, Nagykálló háttérbe szorult Nyíregyháza ellenében, mert elkerülte a vasútvonal.

$\mathrm{Az}$ eleinte magánvasútként működő Tiszavidéki Vasúttársaság államosításáról 1880-ban írták alá a szerződést.

Az I. világháborút a vasútvonal, a Galícia és Oroszország felé lebonyolított jelentős katonai szállítások ellenére, használható állapotban vészelte át. A román csapatok 1919. június 3-án felrobbantották a tokaji Tisza-hidat, ezért a vasúti közlekedés 1921-ig, a híd újjáépítéséig szünetelt.

A II. világháborúban Nyíregyházát 1944. szeptember 6-án ért bombatámadás során az állomásépület és az állomási vágányhálózat megsemmisült. A vonalon napokra megszünt a közlekedés.

A német csapatok 1944 novemberében felrobbantották, a tokaji Tisza-hidat, amelyet csak 1949-re sikerült újjáépíteni. Az egyvágányú vonal villamosítása 1967-ben fejeződött be. A gőzvontatás egészen az 1980-as évek elejéig alkalomszerüen elöfordult a vonalon.

Mezőzombor és Nyíregyháza-Északi-kitérő közötti vonalszakaszon 1970-ben önmüködő térközbiztosító berendezést helyeztek üzembe. A vonalat 1972-ben KÖFI berendezéssel szerelték fel.
A vasúti pálya al- és felépítménye 1979 és1982 között átépítésre került $54 \mathrm{~kg} / \mathrm{fm}$-es sínnel, és alkalmassá vált a $120 \mathrm{~km} / \mathrm{h}$ pályasebességre. Ehhez igazodóan a nyomvonalat is több helyen korrigálták.

\section{HÍDFELÚJÍTÁSI MUNKÁK:}

Aranyos, a Hosszú és a Ladik hidakon 1995. évben hídfákat és a síndilatációs szerkezeteket kicserélték. Új korrózióvédelem, hídfestés készült.

Görbe-hídon 1996. évben hídfákat és a síndilatációs szerkezeteket cseréltek és korrózióvédelem, hídfestés készült.

A meder hídon 1996-1997. évben lokális erősítéseket végeztek, a síndilatációs szerkezetek cseréjét és a teljes korrózióvédelemet megoldották.

Az utolsó felújításra 2015. július 21. és augusztus 30. között került sor, amikoris a meder hídon és a négy ártéri hídon teljes hídgerenda cserét, valamint szórványos sín- és vasbetonalj cserét hajtottak végre.

Az 5 db új építésű híd hossza összesen 622 m, a töltéseké pedig mintegy $1378 \mathrm{~m}$.

Az V/B szárnyvonal az országhatároktól egyvágányú, nemzetközi, villamosított fővonal Budapestig.

Az V/C szárnyvonal, Pécs-Magyarbóly és az országhatár közötti vonalszakasza nem villamosított, Pécs-Dombóvár között egyvágányú, villamosított nemzetközi fővonal.

Az alapfolyosó és a szárnyvonalak átépítése, korszerúsítése az érintett országok egyetértésével történhet.

\section{VÁLTOZÁSOK, VÁLTOZÁSKEZELÉS}

\subsection{Változások}

A magyar társadalmi-gazdasági rendszerváltást követő években, Jugoszlávia több éven át 


\section{Vasúti közlekedés}

tartó felbomlásával megváltozott a szomszédos országok helyzete. Az önálló Horvátország és Szlovénia megalakulásával új államközi kapcsolatok jöttek létre.

Magyarország 1991 óta társult tagja az Uniónak. A csatlakozásunkra 2004 május 1-jén került sor Ciprus, Csehország, Észtország, Lengyelország, Lettország, Litvánia, Málta, Szlovákia és Szlovénia társaságában.

A vasúti közlekedési folyosókkal érintett országok államközi, majd szakértői szinten folytattak egyeztetést az országhatárokon átvezető kapcsolatok fejlesztésére vonatkozóan.

\subsection{Változáskezelés}

Budapesten 1998. április 24-én, a MÁV Rt. Vezérigazgatóságán hat ország nemzeti vasútjának vezérigazgatói, egyetértési nyilatkozatot írtak alá, amely a Velencétől Budapesten át Lembergig húzódó $\mathrm{V}$. számú páneurópai folyosón a vasúti közlekedés korszerüsítésére, rekonstrukciójára és fejlesztésére vonatkozó együttmüködést tartalmazta.

Az egyetértési nyilatkozat öt évre szólt azzal, hogy ha az aláírók részéről ellenvetés nem merült fel, akkor folyamatosan ötévenként meghosszabbodik.

A MÁV Rt. Vezérigazgatóságon 1998-ban, vezérigazgatói biztosként vezettem azt a szakmai teamet, ahol elkészítettük az első, az V. páneurópai alapfolyosóval és szárnyaival kapcsolatos magyar összefoglaló fejlesztési koncepciót, aminek figyelembevételével az alapvetéseket, majd később a szakaszos és részletes engedélyezési tervdokumentációkat, valamint kiviteli terveket kidolgoztuk.

Az alapfolyosó magyar szakaszából, a Zalalövő-Bajánsenye-országhatár vasútvonal hiányzott, ezért döntés született, az őrségi vasút újjáépítéséről, az EU vasúti közlekedési folyosókra elöírt és ajánlott paraméterei alapján.

Az EU 2001-ben megjelent közlekedéspolitikája, a második Fehér Könyv a fenntarthatóságot helyezte előtérbe, ami szerint biztosítani kell:
- a gazdasági növekedést,

- a megfelelő elérhetőséget,

- a környezet minőségének javítását,

- a regionális politikai célkitűzések megvalósítását,

- a kiegyensúlyozott területi fejlődést,

- a kohézió erősítését.

A Fehér Könyv mintegy 60 különböző, közösségi szinten elvégzendő intézkedéscsomagra tesz javaslatot. Külön tartalmaz egy 2010-ig elvégzendő Cselekvési Programot, amelyet 2005-ben felülvizsgálattal erősítettek meg. A könyv összeállításának célja eredetileg az volt, hogy a tagállamok által nemzetgazdasági, szuverenitási okok miatt alapvetően nemzeti érdekkörben tartani kívánt közlekedésfejlesztési intézkedéseket összehangolják és összeurópai dimenziót, fő fejlesztési irányokat szabjanak meg.

\subsection{A Fehér Könyv legfőbb célkitüzései, célterületei:}

A fenntartható mobilitás megőrzése, különösen a növekvő forgalmi igények miatt, így:

- a gazdaság müködéséhez szükséges alapok megerősítése, bővítése,

- a biztonság, balesetmentesség,

- a környezetvédelem,

- az elörelépés a gazdaságilag fenntartható hálózatok felé (díjpolitika),

- az intelligens közlekedési rendszerek bevezetése.

A Fehér Könyv, bár a közlekedés szinte minden területére vonatkozóan tesz javaslatot és megfogalmaz célokat, a megvalósítás módját az egyes tagországok egyeztetéseire bízza. Konkrét dátumokhoz, anyagi forrásokhoz, fejlesztendő konkrét közlekedési módokhoz, helyszínekhez rendelt intézkedések a Fehér Könyvben nem találhatók, ezeket az alacsonyabb szintü országos közlekedési stratégiák, valamint a nemzetközi egyezményeknek számító Operatív Programok, Fejlesztési Tervek, és a közösségi szintű jogszabályok (pl. TENrendelet) tartalmazzák. Megjelenése után jelentős változások történtek Európában a mobilitás terén: új tagokkal bővült az Európai 


\section{Vasúti közlekedés}

Unió, nőttek az üzemanyagárak, emelkedett a közlekedés által okozott környezeti terhelés. Mindezek következtében szükségessé vált a 2010-ig tartó időszakra szóló Fehér Könyv félidei felülvizsgálata. A felülvizsgálatot indokolta még a globalizáció fokozódása, így a különféle közlekedési módok hatékonysága és megbízhatósága alapvető fontosságú lett a versenyképesség szempontjából.

Az egyik legjelentősebb változás a komodalitás, azaz a közlekedési ágak aktív együttmüködése. Erősödött az a követelmény, hogy minden közlekedési mód önmagában is legyen versenyképes, környezetbarát és biztonságos. A közlekedési módok összehangolásával az előbbi tulajdonságok együttes, szinergikus hatását pedig fokozni kell. Cél: a részek közötti kapcsolat javítása révén többleteredmény elérése.

(A 2. rész a 2018. augusztusi számunkban jelenik meg.)

\section{FELHASZNÁLT IRODALOM}

[1] Az Európai Közösséget Létrehozó Szerződés Egységes Szerkezetbe Foglalt Változata (Róma, 1957. 03. 25, utoljára módosítva a 2003-as Csatla kozási Szerződés által), Konszolidált Változat (2004. május 1.) https://goo.gl/4hPBFu (2012. 10. 03.)

[2] A magyar közlekedéspolitikáról és a megvalósításához szükséges legfontosabb feladatokról szóló", 68/1996. (VII.9.) OGY számú határozatában

[3] Zöld Könyv (2009) TEN-T: Szakpolitikai felülvizsgálat. Egy megfelelőbb módon integrált és a közös közlekedéspolitikát szolgáló transzeurópai közlekedési hálózat felé. COM (2009) 44 végleges. Brüsszel, 2009. február 4.

[4] 19/2004 (III.26.) OGY határozat a Magyar Közlekedéspolitikáról (2003-2015)

[5] 2185/2005. (IX. 9.) Korm. határozat a vasúti közlekedéspolitika stratégiai kérdéseiről.

[6] FLEISCHER TAMÁS: Transzeurópai folyosók - a meglévők hosszabbítgatása, vagy egy összeurópai hálózat kialakítása? A délkelet-európai térség és Magyarország Európa közlekedésében: Előadások a bal- kánról 6. Balkán-tanulmányok Központ, Európa Intézet MTA társadalomkutató Központ Budapest, 2006. május 16.

[7] AZ EURÓPAI PARLAMENT ÉS A TANÁCS 913/2010/EU RENDELETE a versenyképes árufuvarozást szolgáló európai vasúti hálózatról (2010. szeptember 22.)

[8] „ZÖLDKÖNYV” TEN-T: Szakpolitikai felülvizsgálat. Egy megfelelőbb módon integrált és a közös közlekedéspolitikát szolgáló transzeurópai közlekedési hálózat felé Brüsszel, 4.2.2009. 04. 02. COM(2009) 44 végleges.

[9] FLEISCHER TAMÁS: Vélemény a TEN-T felülvizsgálatára készített zöld könyvről http://www.vki.hu/ tfleisch/ PDF/p d f 0 9/ Vele m e n y - a - T EN felulvizsgalatara_090402.pdf

[10] FEHÉRKÖNYV, Útiterv az egységes európai közlekedési térség megvalósításához - Úton egy versenyképes és erőforráshatékony közlekedési rendszer felé Brüsszel, 2011.3.28. COM(2011) 144 végleges,

[11] AZ EURÓPAI PARLAMENT ÉS A TANÁCS 661/2010/EU határozata a transzeurópai közlekedési hálózat fejlesztésére vonatkozó uniós iránymutatásokról (2010. július 7.) (átdolgozás)

[12] JAVASLAT: AZ EURÓPAI PARLAMENT ÉS A TANÁCS RENDELETE AZ EURÓPAI ÖSSZEKAPCSOLÓDÁSI ESZKÖZ LÉTREHOZÁSÁRÓL 2011/0302 (COD),COM(2011) 665 VÉGLEGES,

[13] Európai közlekedési hálózatfejlesztés: egy lépéssel közelebb a megállapodáshoz 2012. március 23. https://goo.gl/w64dKw (2012 Szolnoki Tudományos Közlemények XVI. 418

[14] Megállapodtak a tagállamok az infrastruktúra alapról Brüsszel, 2012. június 7. https://goo.gl/P14Ynv (2012.10.05.)(15) Dr. HORVÂTH ATTILA: Közlekedési hálózat és az ország védelmi képesség kapcsolata (védelmi követelmé- nyek a közlekedésfejlesztésben) http://www.biztonsagpolitika. com/userfiles/file/PDF/horvath_attila kozlekedesbiztonsag.pdf (2009. 09.24.)

[15] FELLER TIBOR; HÍDVÉGI GÁBOR; KÖLLER LÁSZLÓ: A nemzetgazdaság és nemzetbiztonság által igényelt „kriti- 


\section{Vasúti közlekedés}

kus infrastruktúra" hálózatok komplex szemléletű vizsgálata (tanulmány): Magyar Mérnöki Kamara Közlekedési Tagozat, Budapest, 2010. https:/goo.gl/7q3t4Z (2012.09.10.)

[16] Új hidak tervezése a Miskolc - Nyíregyháza vasútvonalon prezentáció, VIII.Vasúti $\mathrm{Hi}$ dász Találkozó, 2012 május 30 - június 1, www.mav-thermit.hu//19_KOLLER_Uj_hi-
dak_tervezese_a_Miskolc. Nyíregyhaza vasútvonal. Mezőzombor-Nyíregyháza szakasz jelenlegi és tervezett mütárgyai. ${ }^{\circ}$ Miskolc-Mezőzombor szakasz jelenlegi és tervezett mütárgyai. - Hernádnémeti Hernád-híd. Zádori Gyöngyi SPECIÁLTERV. - Felsőzsolcai Sajó-híd. Závecz Richárd. UTIBER. - többi kis mütárgy. Závecz Richárd. UTIBER. - Tokaj és Rakamaz állomások.

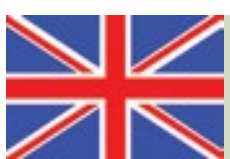

\section{Modernizing the hungarian sections of the 5th pan-european railway corridors and by-lines}

Pan-European transport corridors, also known as the Helsinki corridors, were designated at the European Transport Ministerial Conferences of 1994 and 1997. The ten designated corridors are the extensions of the trans-European transport network (TEN-T) towards Eastern Europe, to the neighbouring states of the then European Union.

The objective of the designation of these corridors was to build good transport links between the EU and its neighbours through the establishment of an efficient and secure transport system, assisting to effectively transport passengers and goods and thereby enhance competitiveness and economic growth.

As a consequence of the enlargement of the European Union, most of these corridors are now in the EU, and are part of the Trans-European Transport Network (TEN-T).

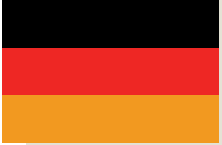

Modernisierung der Ungarischen Abschnitte des 5. Pan-Europäischen Eisenbahnkorridores und Seiner Stichbahnen

Auf den Europäischen Verkehrsministerkonferenzen von 1994 und 1997 wurden paneuropäische Verkehrskorridore, auch bekannt als Helsinki-Korridore, ernannt. Die zehn ausgewiesenen Korridore sind die Erweiterungen des transeuropäischen Verkehrsnetzes (TEN-T) in Richtung Osteuropa zu den Nachbarstaaten der damaligen Europäischen Union.Ziel der Ausweisung dieser Korridore war der Aufbau guter Verkehrsverbindungen zwischen der EU und ihren Nachbarn durch die Schaffung eines effizienten und sicheren Verkehrssystems, das die effektive Beförderung von Passagieren und Gütern unterstützt und somit die Wettbewerbsfähigkeit und das Wirtschaftswachstum fördert. Infolge der Erweiterung der Europäischen Union befinden sich die meisten dieser Korridore jetzt in der EU und sind Teil des transeuropäischen Verkehrsnetzes (TEN-T). 